\title{
KAJIAN SIFAT FISIK DAN KIMIA JERUK SIAM (Citrus nobilis var. microcarpa) SEMBORO BERDASARKAN UMUR SIMPAN MENGGUNAKAN PENGOLAHAN CITRA DIGITAL
}

\author{
Herman Setiawan, Dedy Wirawan Soedibyo, dan Dian Purbasari \\ Jurusan Teknik Pertanian, Fakultas Teknologi Pertanian, Universitas Jember \\ Email: Hermansetiawan95@gmail.com
}

Since hundreds of years ago, orange have grown in Indonesia either naturally or cultivated. One of the most popular places for producing orange varieties is Semboro, Jember Regency. The quality of Semboro oranges is influenced by the level of harvest age and shelf life. In the storage process, Orange expiriences physically and chemical changes at each shelf life which is detrimental. At present the tests performed on Semboro orange are destructive. Based on this, non-destructive measurements are needed by using other methods such as digital image processing. The purpose of this study was to identify the relationship between the physical and chemical properties of Semboro orange based on shelf life. The Semboro Orange used was 150 fruits of super quality with code size 1 and the same picking age of 28 MSB (weeks after flowering). Semboro oranges are stored for 15 days and measured with variations in shelf life of 1,8 and 15 days. This research was conducted in two stages, namely taking pictures and measuring physical and chemical characteristics. Orange samples were then measured interm of physical and chemical properties using the O'hauss pioneer digital scales, penetrometer, refractometer and $\mathrm{pH}$ meter to obtain data on fruit weight, fruit hardness, total dissolved solids and acidity $(\mathrm{pH})$ of the fruit. The value of the image quality variable and the physical and chemical properties were analyzed using one way anova test, correlation, regression, boxplot and validation test.

Keywords-Semboro orange; physical and chemical characteristics; shelf life; image processing

\section{PENDAHULUAN}

Tanaman Jeruk adalah tanaman buah tahunan yang berasal dari Asia. Tiongkok dipercaya sebagai tempat pertama kali jeruk tumbuh. Sejak ratusan tahun yang lalu, jeruk sudah tumbuh di Indonesia baik secara alami atau dibudidayakan. Tanaman jeruk yang ada di Indonesia merupakan peninggalan orang Belanda yang mendatangkan jeruk manis dan keprok dari Amerika dan Italia (Prihatman, 2000).

Menurut Pusat Data dan Informasi Pertanian Kementerian Pertanian pada tahun 2015 produksi jeruk siam di Kabupaten Jember mencapai 131.855 ton. Salah satu tempat penghasil jeruk varietas siam yang terkenal dari Kecamatan Semboro, Kabupaten Jember. Dinamakan Jeruk Semboro karena buah ini pertama kali ditanam di daerah Semboro. Buah ini terkenal dengan cita rasa yang manis, tekstur buah yang lunak, aroma yang segar, dan kulit yang mudah dikelupas (Ridjal, 2008).

Salah satu permasalahan dalam penanganan buah jeruk adalah saat pasca panen. Dalam kegiatan tersebut, perlu dilakukan evaluasi terhadap mutu buah. Dari hasil survey di lapang, petani selama ini mengukur kematangan buah Jeruk Semboro dengan cara manual (melihat ukuran dan warna). Hal ini membutuhkan waktu lama dan akurasi yang didapatkan sangat rendah.

Selama penyimpanan, buah jeruk mengalami perubahan yang sifatnya merugikan pada kualitas mutu buah. Perubahan ini dapat dideteksi dengan pengujian sifat fisik dan kimia pada setiap periode umur simpan buah. Pengujian sifat buah pada umumnya bersifat destruktif (merusak). Dibutuhkan teknologi pengujian yang bersifat tidak merusak dalam penilaian sifat buah.

Salah satu teknologi yang digunakan untuk grading (pemutuan) bahan pertanian adalah pengolahan citra digital. Metode ini mampu menganalisa penampakan suatu bahan berdasarkan ukuran, warna, dan bentuk melalui variabel-variabel citra seperti area, lebar, tinggi, perimeter, dan indeks warna. Cara ini potensial digunakan untuk pengukuran dan pengklasifikasian suatu bahan pertanian secara otomatis, konsisten, akurat, obyektif, serta non destruktif.

Berdasarkan permasalahan diatas, maka diperlukan cara untuk mengkaji hubungan sifat fisik dan kimia Jeruk Semboro untuk mendapatkan variabel-variabel citra yang dapat menduga sifat fisik dan kimia buah Jeruk Semboro berdasarkan umur simpan. Metode pengukuran ini diharapkan dapat memanfaatkan sifat-sifat pengukuran dengan pengolahan citra digital yang konsisten, obyektif, akurat, 
dan tidak merusak (non destruktif). Teknologi ini mampu menghasilkan metode pengukuran sifat fisik dan kimia buah Jeruk Semboro melalui variabel citra berdasarkan umur simpan.

\section{METODOLOGI PENELITIAN}

\section{A. Alat dan Bahan}

Alat-alat yang digunakan adalah kamera, 4 buah lampu TL, seperangkat meja pengambil gambar, kain biru muda sebagai background bahan, software csharp develop 4.2, software microsoft excel, software paint shop pro, blender, refraktometer, penetrometer, timbangan digital o'hauss pioneer, luxmeter, $\mathrm{pH}$ meter. Bahan yang digunakan jeruk Semboro (Citrus nobilis var. microcarpa) dengan jumlah sampel sebanyak 150 buah berkualitas super dan memiliki kode ukuran 1 yang memiliki umur petik yang sama yaitu 28 MSB (minggu setelah berbunga) dan diperoleh dari daerah Semboro, Kabupaten Jember.

\section{B. Prosedur Penelitian}

Penelitian ini akan dilaksanakan melalui dua tahap yaitu pengambilan citra dan pengukuran sifat fisik dan kimia. Penelitian dilakukan di Laboratorium Energi, Otomasi dan Elektrifikasi Pertanian (Enotin) serta Laboratorium Enjinering Hasil Pertanian (EHP) Fakultas Teknologi Pertanian Universitas Jember.

\section{Pengambilan Citra}

Pengambilan citra dilakukan dengan menggunakan kamera digital dan perekaman citra dilakukan dengan software IC Capture 2.2. Hasil perekaman disimpan dalam file bereksistensi bmp. Selanjutnya dilakukan pembuatan program pengolahan citra menggunakan bahasa pemrograman pada aplikasi Sharp Develop dan kemudian dilakukan ekstraksi citra selanjutnya dilakukan proses running untuk mendapatkan variabel citra berupa area, tinggi, lebar, perimeter, indeks warna merah, hijau dan biru. Data hasil ekstraksi disimpan dalam bentuk text.

\section{Pengamatan Sifat Fisik dan Kimia}

Pengamatan sifat fisik dan kimia dilakukan menggunakan alat timbangan digital O'hauss untuk mengukur berat sampel, alat refraktometer untuk mengukur total padatan terlarut, alat penetrometer untuk mengukur kekerasan buah dan $\mathrm{pH}$ meter untuk mengukur derajat keasaman buah. Data hasil pengolahan citra dan pengukuran sifat fisik dan kimia selanjutnya akan dilakukan analisis data menggunakan Anova dan analisis korelasi dan regresi. Diagram alir penelitian disajikan pada Gambar 1.

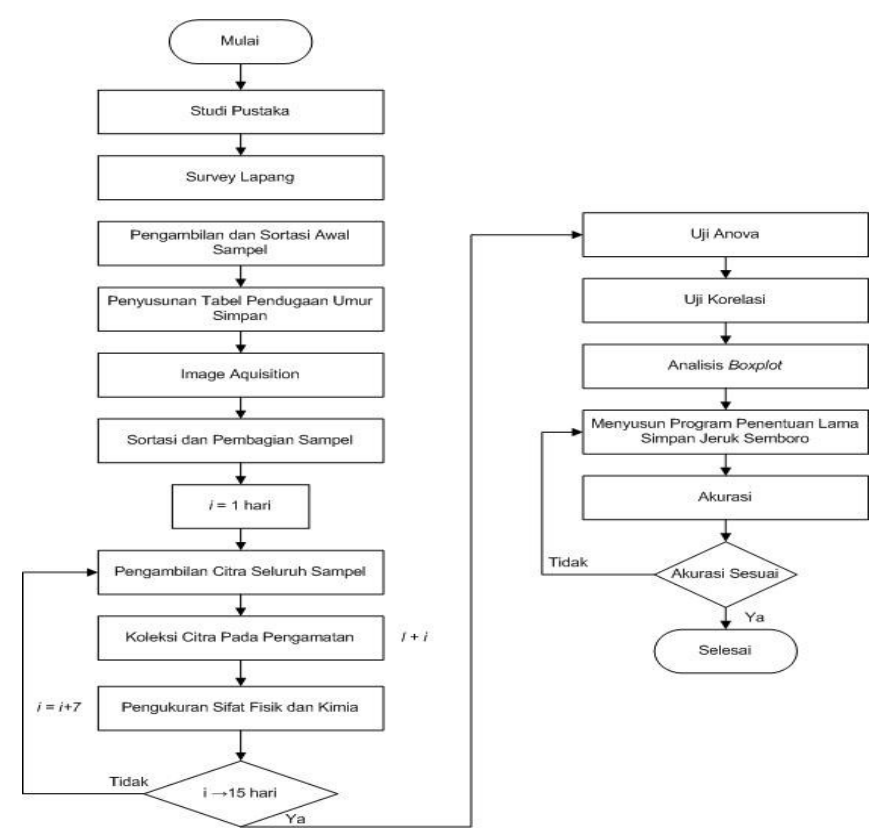

Gambar 1. Diagram alir penelitian 


\section{HASIL DAN PEMBAHASAN}

\section{A. Image Aquisition}

Image Aquisition bertujuan untuk mendapatkan kesesuaian hasil gambar citra dengan keaslian bentuk jeruk semboro. Pada penelitian ini didapatkan Image Aquisition (Gambar 2) yaitu sebagai berikut:

a. Jarak kamera dengan obyek didapatkan jarak yang terbaik yaitu $23 \mathrm{~cm}$ dari kamera ke meja pengambilan gambar dan meletakkan obyek dengan posisi yang teratur.

b. Jarak antara lampu dengan meja pengambilan gambar $44 \mathrm{~cm}$ dan nilai itensitas cahaya lampu sebesar 1983 lux. Berikut merupakan gambar image acquisition dan meja pengambil citra.

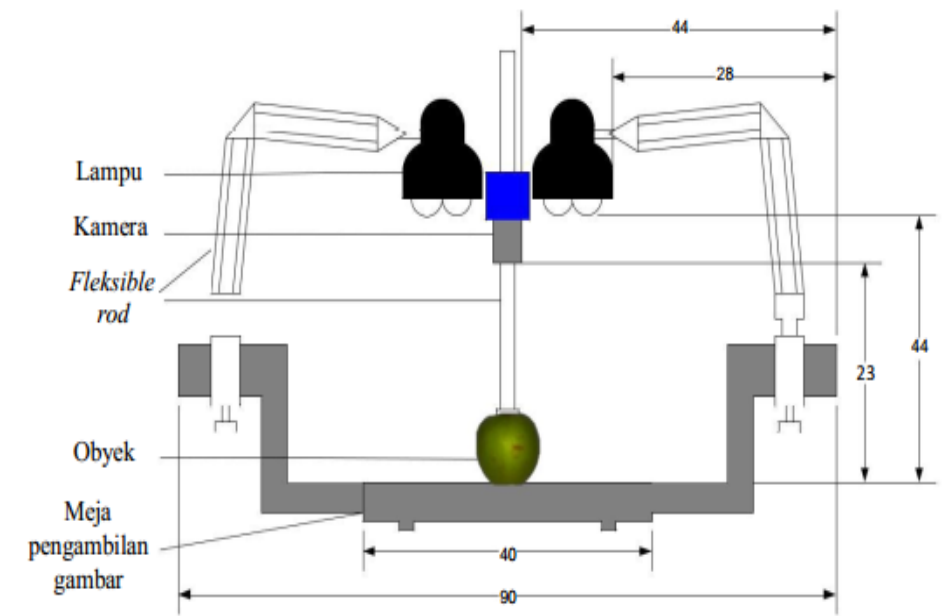

Gambar 2. Image acquisition dan meja pengambil gambar

\section{B. Program Pengolahan Citra}

Citra buah Jeruk Semboro direkam menggunakan softwareIC Capture 6.5 dan kamera Charge Couple Device (CCD) dengan resolusi 1024x768 piksel. Citra buah Jeruk Semboro lalu disimpan dalam file dengan format BMP untuk diolah lebih lanjut. Buah yang digunakan dalam penelitian ini berjumlah 150 yang dibagi dalam 3 umur simpan yaitu umur simpan 1 hari, 8 hari, dan 15 hari. hasil pengambilan citra Jeruk Semboro selama proses penyimpanan dapat dilihat pada Gambar 3.

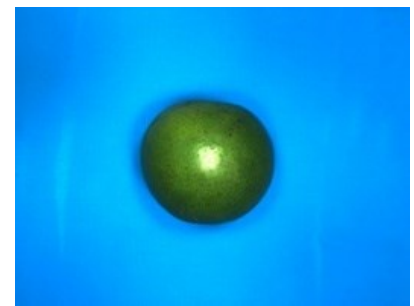

(a) Umur simpan 1 hari

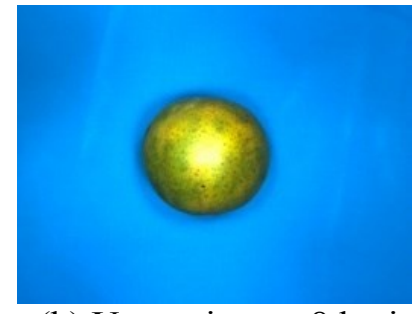

(b) Umur simpan 8 hari

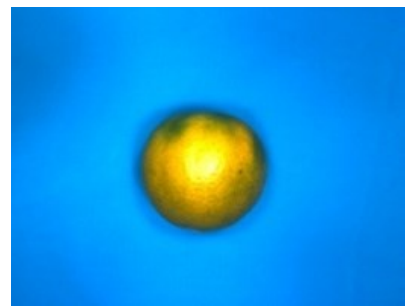

(c) Umur simpan 15 hari

Gambar 3. Hasil Pengambilan Citra Jeruk Semboro berdasarkan Umur Simpan

Program pengolahan citra dibuat menggunakan aplikasi Sharp Develop untuk menghasilkan nilai variabel citra meliputi area, tinggi, lebar, perimeter, indeks warna merah, hijau, biru, nilai pendugaan umur simpan, serta nilai pendugaan sifat fisik/kimia buah. Sifat fisik dan kimia yang diamati meliputi berat, kekerasan, total padatan terlarut, dan $\mathrm{pH}$ buah Jeruk Semboro.

\section{Analisis Anova Variabel Citra dan Sifat Fisik dan Kimia}

Uji anova dilakukan untuk mengetahui perbedaan atau persamaan setiap perlakuan masa simpan. Hasil perhitungan uji anova dapat dilihat pada Tabel 1. 
Tabel 1. Analisis Anova pada Variabel Citra, Variabel Sifat Fisik dan Kimia

\begin{tabular}{ccc}
\hline Variabel & F hitung & F tabel \\
\hline Area & 8,48 & 3,03 \\
Tinggi & 12,53 & 3,03 \\
Lebar & 12,52 & 3,03 \\
Perimeter & 75,31 & 3,03 \\
Indeks warna merah & 202,08 & 3,03 \\
Indeks warna hijau & 121,74 & 3,03 \\
Indeks warna biru & 168,43 & 3,03 \\
Berat & 39,52 & 3,89 \\
Kekerasan & 67,45 & 3,89 \\
TPT & 4,83 & 3,89 \\
pH & 55,55 & 3,89 \\
\hline
\end{tabular}

Berdasarkan Tabel 1 ditunjukkan bahwa semua nilai variabel fisik dan kimia buah Jeruk Semboro mempunyai pengaruh yang berbeda nyata dalam setiap masa simpannya. Nilai rata-rata pada umur simpan 1, 8, dan 15 hari pada variabel mutu citra area, tinggi, lebar, perimeter, indeks warna hijau, dan indeks warna biru mengalami penurunan, sedangkan pada indeks warna merah nilai rataratanya mengalami peningkatan pada setiap umur simpannya. Hal ini dikarenakan selama masa penyimpanan buah akan mengalami perubahan akibat proses respirasi, perubahan ukuran atau area, dan perubahan warna. Perubahan dari warna hijau menjadi kuning pada buah selama proses penyimpanan ini dipengaruhi oleh terjadinya pembentukan zat warna karotenoid.

Selama proses penyimpanan juga mempengaruhi variabel sifat fisik dan kimia seperti berat, kekerasan, dan $\mathrm{pH}$ mengalami penurunan nilai rata-rata, sedangkan nilai rata-rata total padatan terlarut selama penyimpanan meningkat pada setiap umur simpan 1, 8, dan 15 hari. Hal tersebut dapat terjadi karena selama masa penyimpanan, buah mengalami perubahan baik secara fisik maupun kimia diantaranya penurunan kadar air yang menyebabkan buah mengalami penyusutan, terjadinya degradasi pektin dan hemiselulosa yang mengakibatkan buah menjadi lebih lunak, serta penurunan senyawa asam organik dan terjadinya proses degradasi pati pada buah menjadi gula sederhana yang mengakibatkan cita rasa buah menjadi lebih manis.

\section{Analisis Korelasi Umur Simpan dan Variabel Citra}

Analisis korelasi digunakan untuk mengetahui hubungan searah tidaknya antara dua variable atau lebih. Analisis korelasi ditunjukkan pada Tabel 2 berikut.

Tabel 2. Analisis Korelasi Umur Simpan dan Variabel Citra

\begin{tabular}{cccc}
\hline Masa simpan & Variabel & $\mathrm{r}$ & Interval korelasi \\
\hline Area & $-0,987$ & Sangat kuat \\
Tinggi & $-0,967$ & Sangat kuat \\
Lebar & $-0,991$ & Sangat kuat \\
Perimeter & $-0,976$ & Sangat kuat \\
& Indeks warna merah & 0,995 & Sangat kuat \\
1,8 , dan 15 hari & -1 & Sangat kuat \\
& Indeks warna hijau & $-0,988$ & Sangat kuat \\
& Indeks warna biru & 0,990 & Sangat kuat \\
Berat & 0,993 & Sangat kuat \\
& Kekerasan & 0,995 & Sangat kuat \\
TPT & 0,952 & Sangat kuat \\
\hline
\end{tabular}

Tabel 2 menunjukkan bahwa hubungan antara umur simpan dengan variabel citra memiliki nilai korelasi yang besar atau hubungan yang sangat kuat karena mendekati +1 atau -1 . Semakin lama penyimpanan buah Jeruk Semboro menyebabkan buah mengalami perubahan pada area, tinggi, lebar, perimeter, berat, total padatan terlarut, kekerasan dan derajat keasaman. Faktor perubahan area dikarenakan adanya sifat geometri dari objek dalam citra. Secara tidak langsung perubahan bentuk 
yang terjadi pada objek, akan membuat perubahan pada area objek hasil pengambilan citra buah Jeruk Semboro. Ciri-ciri sederhana seperti ukuran, posisi, dan bentuk yang berguna dalam usaha mengenali objek citra yang dianalisis (Usman, 2005:121).Selain itu, menurut Pantastico (1993) selama masa simpan, buah mengalami perubahan yang disebabkan oleh hilangnya klorofil akibat proses fotosintesis dan respirasi yang terjadi di seluruh bagian buah. Perubahan dari warna hijau menjadi kuning pada buah selama proses penyimpanan ini dipengaruhi oleh terjadinya pembentukan zat warna karotenoid.

\section{E. Analisis Korelasi Variabel Citra dengan Variabel Sifat Fisik dan Kimia}

Analisis korelasi dilakukan untuk mencari kekuatan hubungan dan arah linier antara sifat fisik dan kimia (berat, kekerasan, total padatan terlarut, dan derajat keasaman degan variabel mutu citra (area, tinggi, lebar, perimeter, $r, g, b$ ).

a. Korelasi Berat dengan Variabel Mutu Citra

Berdasarkan hubungan antara berat buah dengan variabel mutu citra yaitu area, tinggi, lebar, perimeter, indeks warna merah, indeks warna hijau, indeks warna biru memiliki tingkat hubungan yang sangat kuat. Semakin lama penyimpanan buah maka semakin menurun nilai berat dan nilai variabel citra. Menurut Utama dan Antara (2013) buah setelah dipanen masih hidup dan melanjutkan fungsi metabolisme. Aktivitas metabolisme pada buah dan sayuran segar dicirikan dengan adanya proses respirasi.

b. Korelasi Kekerasan dengan Variabel Citra

Berdasarkan hubungan antara kekerasan dengan variabel citra yaitu area, tinggi, perimeter memiliki tingkat hubungan yang sangat kuat. Semakin lama penyimpanan buah maka semakin meningkat nilai penetrasi (buah semakin lunak) dan nilai variabel citra semakin menurun. Dalam proses penyimpanan ini terjadi degradasi pektat, lignin, selulosa, dan hemiselulosa oleh aktivitas enzim dalam proses pematangan buah. Sehingga terjadi perubahan tekstur dari keras menjadi lunak (Kartasapoetra, 1994).

c. Korelasi Total Padatan Terlarut dengan Variabel Citra

Berdasarkan hubungan antara total padatan terlarut dengan variabel citra memiliki tingkat hubungan yang sangat kuat. Semakin lama penyimpanan buah maka semakin menurun nilai total padatan terlarur dan nilai variabel citra. Peningkatan total padatan terlarut selama penyimpanan disebabkan karena degradasi pati menjadi gula sederhana yaitu glukosa, sukrosa, dan fruktosa (Supriadi, 2015). Hubungan antara total padatan terlarut dengan variabel citra yaitu indeks warna merah, biru dan hijau memiliki tingkat korelasi yang sangat kuat. Semakin lama penyimpanan buah Jeruk Semboro akan mengalami perubahan warna yaitu dari hijau menjadi kekuning-kuningan dengan diikuti perubahan total padatan terlarut pada buah.

d. Korelasi Derajat Keasaman dengan Variabel Citra

Berdasarkan hubungan antara derajat keasaman dengan variabel citra memiliki tingkat hubungan yang sangat kuat. Semakin lama penyimpanan buah maka semakin meningkat nilai derajat keasaman (asam buah berkurang) dan nilai variabel citra semakin menurun. Menurut Novijanto (1997) asam-asam organik menurun selama pemasakan karena kandungan tersebut digunakan di dalam respirasi atau diubah menjadi gula. Asam-asam bisa dianggap sebagai sumber energi cadangan bagi buah-buahan, dan karenanya, bisa diharapkan menurun selama aktivitas metabolisme yang lebih besar yang terjadi selama pemasakan.

\section{F. Analisis Statistik Variabel Citra}

Analisis statistik digunakan untuk mengetahui nilai rata-rata, standar deviasi, Q1, Q2, Q3, minimal, dan maksimal yang nantinya akan digunakan untuk memutuskan untuk input model persamaan logika pada program. Berdasarkan nilai batasan variabel mutu citra didapatkan model persamaan logika atau algoritma pemutuan yaitu:

if(Perim $>=1027.00 \& \&$ Perim $<=1776.00 \& \&$ r_indeks $>=0.2243 \& \&$ r_indeks $<=0.3086)$ umur_simpa n="1 Hari";

if $($ Perim $>=943.00 \& \&$ Perim $<=1286.00 \& \&$ r_indeks $>0.2914 \& \&$ r_indeks $<=0.4483)$ umur_simpan=" 8 Hari"; 
if $($ Perim $>=848.00 \& \&$ Perim $<=1082.00 \& \&$ r_indeks $>=0.3633 \& \&$ r_indeks $<=0.4908)$ umur_simpan ="15 Hari";

\section{G. Integrasi Sifat Fisik dan Kimia Pada Program Berdasarkan Umur Simpan}

Hasil pendugaan masa simpan yang diperoleh program digunakan untuk menampilkan sifat fisik dan kimia yang dimiliki buah yang dianalisis, sehingga perlu digunakan regresi linier agar dapat diketahui hubungan masa simpan dengan sifat fisik dan kimia. Analisis regresi linier antara masa simpan dengan variabel sifat fisik dan kimia buah Jeruk Semboro ditunjukkan Gambar 4 berikut.

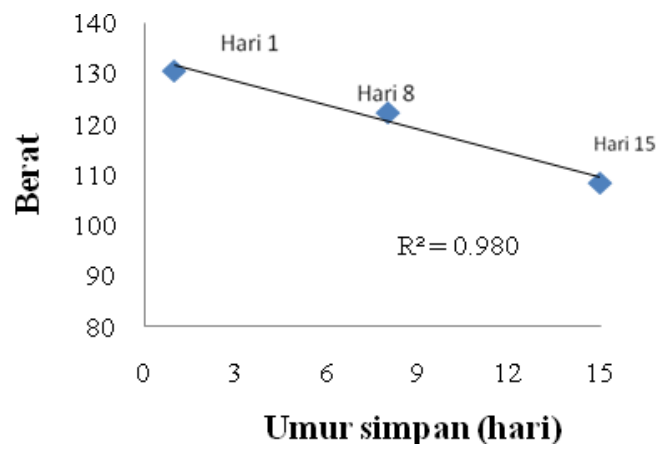

(a) masa simpan dengan berat

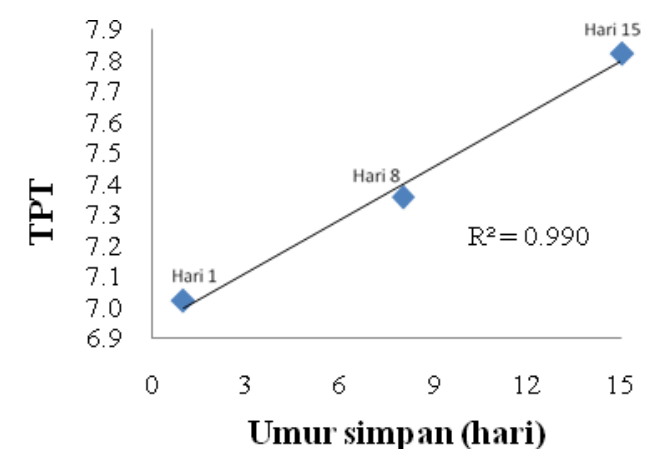

(b) masa simpan dengan total padatan terlarut

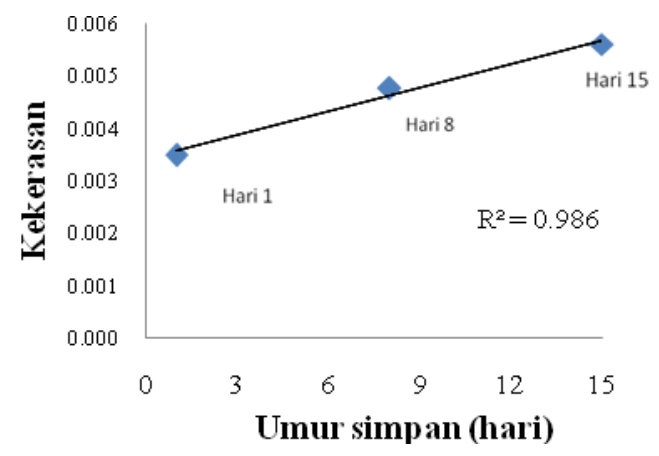

(b) masa simpan dengan kekerasan

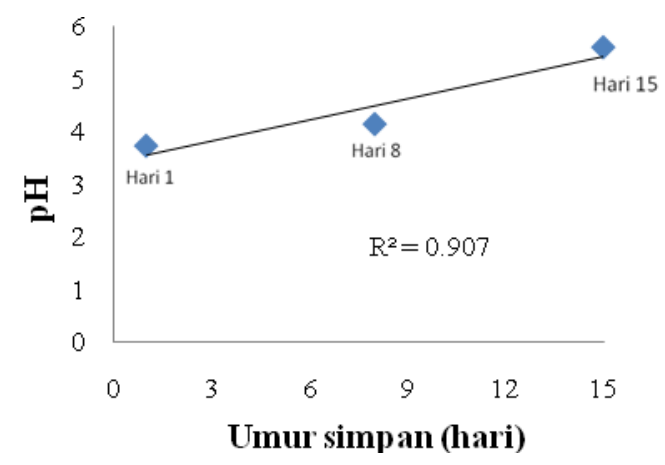

(d) masa simpan dengan $\mathrm{pH}$

Gambar 4. Analisis Regresi Linier Masa Simpan dengan Variabel Sifat Fisik dan Kimia

\section{H. Akurasi Program Pendugaan Umur Simpan Buah Jeruk Semboro}

Nilai akurasi didapatkan dengan menggunakan validasi program terhadap masing-masing umur simpan pada seluruh data yang diambil dengan menggunakan analisis confussion matrix. Akurasi total yang dihasilkan program pendugaan umur simpan buah Jeruk Semboro yaitu sebesar 84,28\%. Hasil analisis confussion matrix dapat di lihat pada Tabel 3.

Tabel 3. Confussion Matrix Hasil Validasi Program

\begin{tabular}{|c|c|c|c|c|c|c|c|}
\hline \multirow{2}{*}{\multicolumn{2}{|c|}{ Masa Simpan }} & \multicolumn{3}{|c|}{ Prediksi } & \multirow{2}{*}{$\begin{array}{l}\text { Total } \\
\text { Baris }\end{array}$} & \multirow{2}{*}{$\begin{array}{l}\text { Akurasi } \\
\text { Produksi }\end{array}$} & \multirow{2}{*}{$\begin{array}{c}\text { Kesalahan } \\
\text { Omisi }\end{array}$} \\
\hline & & 1 Hari & 8 Hari & 15 Hari & & & \\
\hline \multirow[t]{3}{*}{ aktual } & 1 Hari & 15 & 0 & 0 & 15 & 100 & 0 \\
\hline & 8 Hari & 1 & 11 & 3 & 15 & 73.33 & 26.67 \\
\hline & 15 Hari & 0 & 3 & 12 & 15 & 80.00 & 20.00 \\
\hline Total Kolc & & 16 & 14 & 15 & & & \\
\hline Akurasi U & & 93.75 & 78.57 & 80.00 & & & \\
\hline Kesalahan K & & 6.25 & 21.42 & 20.00 & & & \\
\hline
\end{tabular}




\section{KESIMPULAN}

Berdasarkan hasil penelitian diatas dapat disimpulkan bahwa variabel citra dan variabel sifat fisik dan kimia buah Jeruk Semboro mempunyai pengaruh dan hubungan yang kuat hingga sangat kuat berdasarkan variasi umur simpan. Selain itu program yang digunakan pada pendugaan masa simpan buah Jeruk Semboro mempunyai akurasi yang cukup besar yaitu $84,28 \%$

\section{DAFTAR PUSTAKA}

Kartasapoetra, A.G., 1994. Teknologi Penanganan Pascapanen. Jakarta: PT. Rinneke Cifta. Novijanto, N. 1997. Fisiologi dan Teknologi Pasca Panen. Jerber: Universitas Jember.

Pantastico, A. 1993. Fisiologi Pasca Panen, Penanganan dan Pemanfaatan Buah-Buahan dan SayurSayuran Tropika dan Subtropika. Cetakan Ketiga. Yogyakarta:Gadjah Mada University Press.

Prihatman, K. 2000. Jeruk. Jakarta: Sistem Informasi Manajemen Peambangunan di Pedesaan, BAPPENAS.

Pusat Data Dan Sistem Informasi Pertanian Kementerian Pertanian. 2016. Komoditas Pertanian Sub Sektor Hortikultura: Jeruk. ISSN: 1907-1507.

Ridjal, J. A. 2008. Analisis Faktor Determinan Keikutsertaan Petani Berkelompok, Pendapatan, dan Pemasaran Jeruk Siam di Kabupaten Jember. Jember. Pasca Sarjana Manajemen Agribisnis Universitas Jember.

Supriadi, H. 2015. Pengaruh Penambahan Nanopartikel Zno dan Kalium Sorbat Pada Edible Coating Karagenan dalam Mempertahankan Kesegaran Buah Stroberi (Fragaria Sp.) Segar. Skripsi. Bogor: Fakultas Teknologi Pertanian IPB. [01 September 2018]

Usman, A. 2005. Pengolahan Citra Digital dan Teknik Pemrogramannya. Yogyakarta: Graha Ilmu.

Utama, I. M. S dan Antara, N. S. 2013. Pasca Panen Tanaman Tropika: Buah dan Sayur. Modul Kuliah. Denpasar: Universitas Udayana. 